\title{
A Critical Review of Three Theoretical Approaches on Knowledge Transfer in Cooperative Alliances
}

\author{
Qiang Ding (Corresponding author) \\ Department of Strategy \& Human Resource Management \\ Waikato Management School \\ The University of Waikato \\ Private Bag 3105, Hamilton, New Zealand \\ E-mail: qd8@waikato.ac.nz \\ Michele E.M. Akoorie \\ Department of Strategy and Human Resource Management \\ Waikato Management School \\ The University of Waikato \\ Private Bag 3105, Hamilton, New Zealand \\ E-mail: mema@waikato.ac.nz \\ Kathryn Pavlovich \\ Department of Strategy \& Human Resource Management \\ Waikato Management School \\ The University of Waikato \\ Private Bag 3105, Hamilton, New Zealand \\ E-mail: KPAV@waikato.ac.nz
}

\begin{abstract}
Knowledge transfer has been acknowledged as the conveyance of knowledge between actors in an exchange relationship. Inter-firm knowledge transfer considerations are particularly applicable to the viability of cooperative alliances. This paper attempts to identify and demonstrate the limitations and gaps in the existing theoretical approaches when it comes to understanding the phenomena of inter-organizational knowledge transfer relying on alliances in the competitive and changing environment.
\end{abstract}

Keywords: Knowledge transfer, Cooperative alliances, Transaction cost economics (TCE), Resource-based theory (RBT), Knowledge-based view (KBV)

\section{Emergence of Inter-organizational cooperation}

Over the past two decades, although inter-organizational cooperation is often described as being inherently fragile and unstable in nature with high failure rates (Geringer \& Hebert, 1991; Inkpen \& Beamish, 1997; Albers, 2005), inter-organizational cooperation have increased every year. The benefits of inter-organizational cooperation have been recognized worldwide, and inter-organizational cooperation has been utilized substantially in nearly all industry sectors (Pavlovich \& Akoorie, 2003; Hyder \& Abraha, 2003).

Inter-organizational cooperation can be regarded as the important component of corporate strategy undertaken by involved firms in an intentional facilitating manner according to some definite strategic goals (Gulati, 1998; Ariño \& Reuer, 2004; Albers, 2005). It normally involves two or more parties engaging in the development and operation of a new business entity both in the domestic and international markets (Hagedoorn \& Schakenraad, 1994; Bleeke \& Ernst, 1995).

Inter-organizational cooperation can encompass several institutionalized forms that range from just short of mergers and 
acquisitions (when one firm absorbs most of the stock of another) to informal arrangements to work together (Harrigan, 1986), such as alliances, license co-production agreements, value chain partnerships etc. (Hyder \& Abraha, 2003), as shown in Figure 1.

Various forms of inter-organizational cooperation modes depict the important changing landscape accruing in organizational management practices - no longer are organizations operating independently, but rather there is flexible interdependency and co-development among various types of firms (Pavlovich \& Akoorie, 2003; Child \& Faulkner, 1998). These collaborative alliances phenomena illustrate the changing landscape of organizational management based upon partnerships and interdependence. In fact, if the disadvantages of inter-organizational cooperation can be reduced to a certain degree, companies could seek the mechanism of cooperation to acquire each other's resources and skills that they cannot develop with its own efforts (Albers, 2005).

\section{Value of Knowledge-Driven Inter-organizational Cooperation}

Researchers seeking to explain the alliance trend have argued that inter-organizational cooperation provides a platform for maximizing long-term profitability - either by increasing sales or decreasing costs, or both. Other common motives include capturing increased economies of scale (Newburry \& Zeira, 1997), being cost-effective and efficient in the height of the globalization of markets (Datta, 1988; Harrigan, 1985, 1986), local market channel access (Harbison, 1996; Gomes-Casseres, 1989). Researchers particularly note access to resources, core competencies, innovative skills, and country-specific knowledge as the primary goals for business firms (Kogut, 1988; Ireland, Hitt, Vaidyanath, 2002; Eunni, Kasuganti \& Kos, 2006; Inkpen, 2002). In many industries, increasingly rapid technological update and competition results in alliances intending to access knowledge, skills, and resources beyond firm boundaries. Companies that are capital-rich but knowledge resource-poor are attracted to collaborative alliance ventures (Inkpen, 2002; Schuler \& Tarique, 2006).

Albers (2005) explains the resource access motive in alliance formation as the advantage of two firms joining their complementary resources. In doing so, they achieve time advantages in comparison to the alternative of developing or acquiring the needed resources alone. Pavlovich and Akoorie (2003) also emphasize the 'partnering' of firms, from various industrial sectors, as developing rich and fine-grained knowledge exchanges to build and innovating organizations. These organizations can flourish if they can be managed effectively and efficiently. Table 1 provides three alternative ways of accessing knowledge resources, which is either through the market, internal development or through alliance formation. With these in mind, taking business in inter-organizational cooperative arrangements has thus enabled organizations to consider every potential opportunity to promote their products or services at some level (Hill, 2005). This is not only important for organizational growth, but is essential to gain an advantage and stay a step ahead of the opposition - a key strategy for modern corporations.

The above comments provide the theoretical perspectives on the benefits for organizations to enter into cooperative arrangements (Hyder \& Abraha, 2003). With regard to the explanations of the phenomena of resource access based on organizational cooperation, three schools of thought are discussed in the following sections. These are Transaction Cost Economics (TCE), Resource-Based Theory (RBT) and Knowledge-Based Theory (KBT).

\section{Three theoretical approaches}

\subsection{Transaction Cost Economics (TCE)}

Organizational theorists have correctly argued that management lies at the intersection of variety of disciplines, including economics, sociology, and psychology. Transaction cost economics theory (TCE) is thought to be most useful for integrating the economic implication of organizational behavior into a strategic analysis of the firm (Kogut, 1988; Parkhe, 1993).

TCE analysis is oriented specifically towards the minimization of the costs of the transactions among various assets (Williamson, 1975, 1985; Zajac \& Olsen, 1993; Tallman, 2005). Transaction costs include all the expenses and fees when preparing and implementing contracts and agreements, dealing with incurred legal claims about the terms and conditions, stabilizing the working relationship and expanding the investment channels, etc. (Kogut, 1988). The transaction cost approach suggests that firms will establish alliances when the cost incurred is perceived to be lower than that involved in full integration of the given activity within the existing corporate hierarchy (Hennart, 1991).

Benefits of TCE - TCE can effectively define the various organizational relationships, boundary structures and activities (Pearce, 1997). According to the TCE view, any governance mechanism is formed because this mechanism is an efficient and not expensive means to govern the particular exchange. An alliance is attractive when it economizes on governance costs in a particular transaction (Tallman, 2005). Kogut (1988) analyzed the motivation of a firm's knowledge transfer behavior via the alliance from a transaction cost perspective. Firms will engage in alliances only if inter-organizational knowledge transfers are more efficient than market means. The condition most likely to foster alliance learning behavior is the environmental uncertainties that would affect and monitor a firm's market activities. In order to avoid this uncertainty, two or more collaborative partners are put in a mutual hostage position through joint 
commitment of resources/knowledge. This mutual hostage position functions as a superior mechanism resulting in the sharing of technologies, achieving alignment of incentives and then guaranteeing performance through agreement on the division of profits or costs.

According to the principle proposed by Williamson (1975; 1985), if there is a high frequency of interaction and a great deal of asset specificity, then vertical integration will occur. Therefore, TCE is useful for explaining the movement toward vertical integration (Alter \& Hage, 1992). TCE contributes to our understanding of knowledge transfer in alliances. It considers the conceptual significance of knowledge transfer, identifies partner firms' resource provisions and provides a greater understanding of cost-benefit comparisons under this unique form of organizational cooperation (Yan, 2000). Some researchers point out, when dealing with the cross-border business activities, it is rational to regard an alliance arrangement as an alternative means to extend the current hierarchical structures, to minimize coordination expenses, and to improve the scale and scope of knowledge exchange and communication frequencies (e.g., Hennart, 1988, 1989; Kogut \& Zander, 1992, 1993). TCE especially clarifies the tacit knowledge transfer activities and equity assets' investment through alliances. Based on his empirical research findings, Killing (1983) verifies that because of the intensive personnel interactions, such as meetings between the involved participants, the positive effects of tacit knowledge transfer can be amplified. Participants take an more active approach to conduct the business operations.

Limitations of TCE - However, various researchers point out that there are grave limitations and weaknesses in the transaction cost approach in explaining alliance learning behavior (Alter \& Hage, 1992; Kogut, 1988). Transaction cost theory has been criticized in that it emphasizes the importance of transaction behavior only, while ignoring other relevant opportunities and advantages, such as the integrated competitive abilities and value creation brought about by this particular inter-organizational cooperative form (Yan, 2000). In another major criticism of transaction cost analysis, Kogut (1988) argues that a transaction explanation of alliances learning is driven by consideration of cost-minimization, but, actually, the decision to engage in the alliance knowledge transfer may represent a more costly, though ultimately more profitable, alternative.

A more fundamental limitation of the transaction cost approach is that it makes assumptions about the nature of human beings and organizations that have been criticized as being restrictive and culturally bound (Alter \& Hage, 1992; Doz \& Prahalad, 1991). Transaction cost theory assumes that there exists an anti-trust tendency in the nature of human beings and organizations and that people always want to maximize profits in all business activities. Consequently, where there are small numbers of players and dependency between them, there is opportunism. While this assumption is valid in analyzing specific types of organizational behavior in the United States context, evidence reveals differences across societies, particularly between the societies in East Asia and those of the West (Boisot \& Child, 1988). It is argued that there is a movement in organizational behavior toward greater trust and dependency - which include all levels of inter-organizational collaboration - and away from a maximization of profits, even when only small numbers are involved (Alter \& Hage, 1992; Doz \& Prahalad, 1991).

\subsection{Resource-Based Theory (RBT)}

RBT is an alternative to transaction cost economics for explaining firm integration (Kogut \& Zander, 1993). The premise is that firms forgo arm's-length arrangements (e.g., licensing) and pursue joint equity ventures and wholly-owned subsidiaries not necessarily to reduce transaction costs, but because higher levels of integration provide a more effective means of transferring know-how that is tacit, difficult to imitate, and likely to lead to above-normal returns (Kogut \& Zander, 1993). RBT suggests that firm's resources and capabilities influence the growth and performance of the firm (Barney \& Clark, 2007). The firm is defined as a set of productive resources and administrative organizations (Penrose, 1959). The primary concern of RBT when the theory was first introduced was which characteristics could generate sustained competitive advantages. The question is why firms exhibit varying performance within the same industry (McGunagle, 2007).

RBT posits that the resources, assets, and capabilities can be combinative and cumulative in nature (Barney \& Clark, 2007). Each bundle of strategic and complementary resources has a particular rent-generating potential that changes with resource variations and is highly dependent on management capabilities (Tallman, 2005). The basic premises of the RBT are that firms are differently equipped with more or less strategically relevant resources and these resources are not easily transferable across firms.

Obviously, the essential notion of the RBT is that all assets, capabilities, organizational processes, firm attributes, information, knowledge, etc. controlled by a firm enable the firm to implement strategies that improve its efficiency and effectiveness (Barney \& Clark, 2007). A firm's resources are called strategic resources if they become the source of sustained competitive advantage (SCA) (Albers, 2005), and SCA will exist if efforts to duplicate this advantage by competitors have been terminated. As Barney (1991, p. 105) argues, to ensure SCA, "four attributes of the firm's resources are inevitable, i.e. valuable; rare; imperfectly imitable; and substitutability".

Resources are considered as "valuable for the firm if they improve the firm's effectiveness and efficiency" (Barney, 1991, p. 106), that is to say, the resources contribute to reduced costs or increased revenues. Resources are rare if no or 
only a small number of potential and present competitors possess these same resources as well. If a large number of firms had control over the same valuable resource, all of these firms have the opportunity to exploit this resource, therefore no single firm has an advantage over the others. That is to say, a valuable but common resource can allow a firm to survive but it will not post an outstanding performance vis-à-vis its competitors (Barney, 1991). Resources are considered as imperfectly imitable, if firms can obtain them at significant additional costs. The last attribute, substitutability, is closely linked to the imperfectly imitable attribute (Albers, 2005). Obviously, if a resource which is valuable, rare, and imperfectly imitable but there is an appropriate substitute, the competitive advantage would be undermined.

In summary, according to the resource-based view, a firm that possesses and succeed in exploiting its resources with the characteristics discussed earlier can maintain a sustainable competitive advantage and perform at a higher level than the industry average (Barney \& Clark, 2007). A firm can create a competitive advantage when it is implementing a value-creating strategy which is not simultaneously being implemented by a large number of firms. Various factors, such as a firm's history, casual ambiguity, and interconnectedness, may increase the inimitability of resources. Firm's resources that do not have strategically equivalent resources are non-substitutable resources. A firm may gain sustained competitive advantages when other firms may not obtain the same competitive advantage using different resources (McGunagle, 2007). The model of RBT is illustrated in Figure 2.

The applicability of the resource-based view on inter-firm knowledge transfer in cooperative alliances is commonly acknowledged although it is still in its infancy (Das \& Teng, 2000). Basically, two rationales for cooperation can be identified from a RBV perspective. First, a more transparent motive can be labeled as resource access. A firm should cooperate if cooperation provides access to strategic resources in a shorter time and/or at lower costs compared to developing the resources alone (Albers, 2005). The second motive can be labeled as the retaining of its own resources (Das \& Teng, 2000). This motive is relevant if strategic resources exist that are currently not employed by the firm. Through a resource-based perspective, the underlying argument is to attain sustained competitive advantage (SCA) since the relevant external and internal resources and assets are heterogeneous for firms (Hyder \& Abraha, 2003).

With regard to the empirically observed motives mentioned above, the RBT clearly helps to explain all components of the resource access motive and economies of scale. Clearly, the combination of specific resources could reduce product development phases and underscore the significance of the resource access motive (Albers, 2005). RBT also focuses on organizational learning (McGunagle, 2007). The renewal and development of resource-based advantages through learning is essential (Kogut \& Zander, 1992). When a firm can learn from its partners, it may also contribute to the firm's competitive advantage. The intensity and diversity of learning from local partners facilitates local knowledge acquisition and strengthen firm performance in host countries.

The RBT asserts that entries are not only 'pushed' by firm-specific advantages possessed by the MNC, but also 'pulled' by the resources and capabilities of the target firm abroad, which may help the investing MNC develop new advantages (McGunagle, 2007). In the strategic management literature, some researchers further extend the resource-based view (RBV) first identified by Penrose in 1959 and clarify the knowledge-based view (KBV).

\subsection{Knowledge-Based View (KBV)}

Knowledge creation rather than imitation is a difficult task and quite expensive to do. The central subject of KBV, which examines how to effectively and efficiently conduct knowledge management, is thus now increasingly attracting managers and researchers worldwide (Grant, 2002). The KBV argues that knowledge is a firm's most important and primary resource (Grant, 2002; McEvily \& Chakravarthy, 2002). Researchers adopting the KBV perspective highlight that the firm's future growth is dependent on the productive integration of knowledge resources and derivative decision-making capabilities (Spender, 1996). A firm's competitive advantage comes from the coordination and combination of different knowledge resources at the firm level rather than the individual level through business activities (Spender, 1996). It is knowledge (especially the complex, tacit and heterogeneous knowledge which is hard to imitate) rather than raw materials that provide the driving forces for the alliances' competitiveness and performance (Barney, 1991).

Therefore, companies can be seen as systems of social knowledge inputs (Kogut \& Zander, 1993, p. 627; Grant, 2002). Companies are "required to integrate the specialized and idiosyncratic knowledge, thus to constitute the coordination for generating advantage, creating returns" (Demsetz, 1991, p. 172), and developing relevant organizational abilities (Knight \& Cavusgil, 2004). In most situations, there exists mutual reinforcing relationship between knowledge and capabilities. This means that companies acquiring knowledge can improve their organizational capabilities. Meanwhile, the organizational capabilities can enable companies to create new knowledge. As stated by Tallman and Fladmoe-Linquist (2002), these movements potentially lead to a virtuous cycle.

A knowledge-based perspective addresses the resources and capabilities of the alliance and, in particular, the transfer of critical know-how from the parents to the alliance (Steensma \& Lyles, 2000). At the core of the KBV perspective is that an organization's idiosyncratic know-how and its ability to replicate and exploit knowledge are fundamentally 
responsible for organizational success (Barney, 1991; Kogut, 1988). The strategic potential of knowledge, however, depends on certain characteristics of that knowledge. It must be simultaneously valuable, difficult to imitate, and limited in prevalence among the competitors in order to earn the organization above-normal returns (Barney, 1991; Barney \& Clark, 2007).

According to the knowledge-based theory, strategic alliances are used to access other firm's resources and for knowledge enhancement in certain critical functional areas, as the required knowledge cannot be developed through its own ability (Madhok, 1996). The premise is that firms forgo arm's-length arrangements (e.g., licensing) and pursue joint equity ventures and wholly-owned subsidiaries not necessarily to reduce transaction costs, but because higher levels of integration provide a more effective means of transferring know-how that is tacit, difficult to imitate, and likely to lead to above-normal returns (Kogut \& Zander, 1993). Knowledge transfer considerations are particularly applicable to the viability of alliances. The relatively interdependent relationship between the partner firms enables more face-to-face interaction and closer working relationships than non-equity arrangements and contracts. The shared equity arrangements are believed to be effective vehicles for transferring tacit know-how (Mowery, Oxley \& Silverman, 1996). Building on the knowledge-based approach, while alliances sometimes bring together partners making similar contributions, e.g. sharing the risks of assets' investment, it seems they are more frequently contribute and integrate complementary inputs and attributes. Hence, a knowledge-based perspective addresses the resources and capabilities of the alliance and, in particular, the transfer of critical know-how in the alliance (Steensma \& Lyles, 2000). The knowledge-based perspective is thus an alternative to resource-based view for explaining firm integration. Following on Ireland, Hitt and Vaidyanath's (2002) classification, this paper uses the term 'knowledge' referring to those skills, capabilities, processes which could be critical to enhancing organizational competitiveness.

\subsection{Theoretical critique}

There are many theoretical perspectives that are used to explain various aspects of inter-firm knowledge transfer phenomena. Each makes a singular contribution to our understanding, though a generally accepted and unifying theory is still largely absent (Parkhe, 1993; Child \& Faulkner, 1998). Specific contributions include the identification of antecedent conditions that provide a strategic rational for entering alliances, the anticipation of specific returns, and the selection of a governance structure. Given particular affinities with either economics or organization theory, they exhibit distinct features. Although a unified theory is not yet available, "it is possible to offer a systematic overview of the main perspectives which contribute to our understanding of the research topic and to draw some comparisons between them" (Child \& Faulkner, 1998, p. 17). Indeed, a review and comparison of the most common theoretical frameworks may illustrate this.

Transaction cost theory can be regarded as the predominant theory underlying research on inter-organizational knowledge transfer (Das \& Teng, 2000), which provides a fundamentally different explanations for knowledge transfer compared to the RBT (Albers, 2005). While the RBT focuses on the firm as a whole and examining the environmental implications deriving recommendations for its strategy formulation, transaction cost theory focuses on the individual transaction (Williamson, 1996), not the firm as a predefined organization. A transaction is thereby defined basically as an economic exchange based on a contract (Williamson, 1975, 1996). The major strength of the transaction cost theory lies with a firm's capacity to achieve efficiency by having hierarchical control; however, control can also be a source of weakness since it can become a hindrance to the other partner who may avail itself opportunistically of the weaknesses inherent in the control structure (Hyder \& Abraha, 2003). The assumptions underlying transaction cost theory also emphasize the importance of cost minimization and efficiency rather than issues related to profit maximization and seek to identify and exploit competitive advantages for the organizations vis-à-vis its competitors (Albers, 2005).

The resource-based theory (RBT) and knowledge-based view emphasizes the importance of unique competencies or capabilities (such as patents, knowledge, technologies, brands, or processes), which when leveraged, can provide firms with a sustainable competitive advantage and suggest that firms form alliances to exchange complementary knowledge (Li \& Shenkar, 1996).

RBT also suggests that alliances differences result from imperfect processes of learning and knowledge accumulation (Grant, 2002; Barney, 1991; Barney \& Clark, 2007). Both the resource-based view (RBV) and knowledge-based view (KBV) consider firms as resources (knowledge) repositories, and concentrate on how these resources (knowledge) can be organized to attain competitive advantage for the collaborating firms (Faulkner \& De Rond, 2000).

There are several advantages to these approaches. First, they seek to develop competitive advantage for the collaborating firms. Second, they try to maximize long-run profits through using and developing firm resources (knowledge) (Tsang, 1998). Finally, they create opportunities for learning of knowledge by partners (Hyder \& Abraha, 2003). Some researchers compare the differences between the resource-based view and transaction cost approach on strategic alliance formation, and have come to the following contrasting conclusions (Eisenhardt \& Schoonhoven, 1996): 
1) Strategic and social factors are more important than transaction costs;

2) Characteristics of the firm (e.g. strategy, top management) outweigh transaction details; and

3) A theoretical logic of needs and opportunities overshadows efficiency issues.

\section{Concluding remarks}

In sum, theoretical explanations go some way towards explaining the increased use of the alliance mode, which means that a company can be involved in cooperative arrangements in different market areas and with different partners at the same time, bringing different strengths to each partnership as they are needed, such as knowledge of the market in a particular region, or the capital needed for an important investment. In some countries, alliances are the only acceptable and possible form with local partner/s; the firm could reduce liabilities of foreignness and obtain insights about the local environment, thus increasing the likelihood of success (Li \& Shenkar, 1996). Pavlovich and Akoorie (2003) point out that different knowledge is owned by different partners and that the alliance phenomenon is not entirely unexpected given that knowledge could not be obtained by other means. Therefore, learning expectations and goals exist even in alliances that were formed for strategic, operational or financial motivations, and this alliance knowledge transfer phenomenon particularly occurs in knowledge intensive or high-tech industries.

Each of the principal theories reviewed in the above sections contributes in some way to explaining and justifying strategies of cooperation and knowledge transfer in fiercely competitive environments (Faulkner \& De Rond, 2000). None of these explanations should be seen as being superior to another, and it cannot be assumed that knowledge transfer in alliances is always prompted by single aim. In fact, it is helpful if we view these explanations as being complementary rather than contradictory.

\section{References}

Albers, S. (2005). The Design of Alliance Governance Systems. Koln: Kolner Wissenschaftsverlag.

Alter, C., \& Hage, J. (1992). Organizations Working Together. Newbury Park, CA: Sage Publications.

Ariño, A., \& Reuer, J. (2004). Designing and Renegotiating Strategic Alliance Contracts. Academy of Management Executive, 3, 37-48.

Barney, J. B. (1991). Firm Resources and Sustained Competitive Advantage. Journal of Management, $17,33-46$.

Barney, J.B. \& Clark, D.N. (2007). Resource-Based Theory: Creating and Sustaining Competitive Advantage. New York: Oxford University Press.

Bleeke, J. \& D. Ernst. (1995). Is Your Strategic Alliance Really a Sale? Harvard Business Review, 73(1), 97-105.

Boisot, M \& Child, J. (1988). The Iron Law of Fiefs: Bureaucratic Failure and the Problem of Governance in the Chinese Economic Reforms. Administrative Science Quarterly, 33, 507-27.

Child, J. \& Faulkner, D.O. (1998). Strategies of Cooperation: Managing Alliances, Networks, and Joint Ventures. Oxford: Oxford University Press.

Das, T.K., \& Teng, B. (2000). A Resource-based Theory of Strategic Alliances. Journal of Management, 26, 31-61.

Datta, D. (1988). International Joint Ventures. Journal of General Management, 14(2), 78-91.

Demsetz, H. (1991). The Theory of the Firm Revisited. In Williamson and Winter (Eds.), The Nature of the Firm (pp. 159-178). New York: Oxford University Press.

Doz, Y. \& Prahalad, C.K. (1991). Managing DMNCs: A Search for a New Paradigm. Strategic Management Journal, $12,145-164$.

Eisenhardt, K.M. \& Schoonhoven, C.B. (1996). Resource-based View of Strategic Alliance Formation: Strategic and Social Effects in Entrepreneurial Firm. Organization Science, 7(2), 136-150.

Eunni, R.V., Kasuganti, R.R. \& Kos, A.J. (2006). Knowledge Management Processes International Business Alliances: A Review of Empirical Research, 1990-2003. International Journal of Management, March, 23, 1.

Faulkner, D. \& De Rond, M. (2000). Perspectives on Cooperative Strategy. In D. O. Faulkner and M. de Rond (Eds.), Cooperative Strategy: Economic, Business, and Organizational Issues. Oxford University Press.

Geringer, J.M. \& Hebert, L. (1991). Measuring Performance of International Joint Ventures. Journal of International Business Studies, 22, 249-263.

Gomes-Casseres, B. (1989). Ownership Structure of Foreign Subsidiaries: Theory and Evidence. Journal of Economic Behaviour and Organization, 11, 1-25.

Grant, R.M. (2002). The Knowledge-based View of the Firm. In Choo, C.W. and Bontis, N. (Eds.), The Strategic Management of Intellectual Capital and Organizational Knowledge (pp.133-148). Oxford: Oxford University Press. 
Gulati, R. (1998). Alliances and Networks. Strategic Management Journal, 19 (4, Special Supplement), 293-317.

Hagedoorn, J. \& J. Schakenraad (1994). The Effect of Strategic Technology Alliances on Company Performance. Strategic Management Journal, 15(4), 291-309.

Harbison, J. (1996). Strategic Alliances: Gaining a Competitive Advantage. New York: Conference Board.

Harrigan, K. R. (1985). Strategies for Joint Ventures. Lexington, MA: Lexington Books.

Harrigan, K. R. (1986). Managing for Joint Venture Success. Lexington, Mass.: Lexington Books.

Hennart, J.F. (1988). A Transaction Cost Theory of Equity Joint Ventures. Strategic Management Journal, 9, 361-374.

Hennart, J.F. (1989). Can the 'New Forms of Investment' Substitute for the 'Old Forms'? A Transaction Costs Perspective. Journal of international business studies, 20, 211-34.

Hennart, J.F. (1991). The Transaction Costs Theory of Joint Ventures: An Empirical Study of Japanese Subsidiaries in the United States. Management Science, 37, 483-497.

Hill, C. (2005). International Business: Competing in the Global Marketplace (5 $\left.5^{\text {th }}\right)$. New York: McGraw-Hill Irwin.

Hyder, A.S. \& Abraha, A. (2003). Strategic Alliances in Eastern and Central Europe. Oxford: Elsevier Science.

Inkpen, A. C. (2002). Learning, Knowledge Management, and Strategic Alliances: So Many Studies, So Many Unanswered Questions. In F. Contractor \& P. Lorange (Eds.), Cooperative Strategies and Alliances (pp. 267-289). Amsterdam: Pergamon.

Inkpen, A.C. \& Beamish, P.W. (1997). Knowledge, Bargaining Power, and the Instability of International Joint Ventures. Academy of Management Review, 22(1), 177-203.

Ireland, R.D., Hitt, M.A., Vaidyanath, D. (2002). Alliance Management as a Source of Competitive Advantage. Journal of Management, 28(3), 413-446.

Killing, P. J. (1983). Strategies for Joint Venture Success. New York: Praeger Publishers.

Knight, G.A. \& S.T. Cavusgil (2004). Innovation, Organizational Capabilities, and the Born-Global Firm. Journal of International Business Studies, 35(2), 124-141.

Kogut, B. \& Zander, U. (1992). Knowledge of the Firm, Combinative Capabilities, and the Replication of Technology. Organization Science, 3(2), 383-397.

Kogut, B. \& Zander, U. (1993). Knowledge of the Firm and the Evolutionary Theory of the Multinational Corporation. Journal of International Business Studies, 24(4), 625-645.

Kogut, B. (1988). Joint ventures: Theoretical and Empirical Perspectives. Strategic Management Journal, 9, 319-332.

Li, J.T. \& Shenkar, O. (1996). In Search of Complementary Assets: Cooperative Strategies and Knowledge by Prospective Chinese Partners. In Child, J. \& Lu, Y. (Eds.), Management Issues in China: Vol. 2, International Enterprises. London: Routledge.

Madhok A. (1996). The Organization of Economic Activity: Transaction Costs, Firm Capabilities, and the Nature of Governance. Organization Science, 7, 577-590.

McEvily, S.K. \& Chakravarthy, B. (2002). The Persistence of Knowledge-based Advantage: An Empirical Test for Product Performance and Technological Knowledge. Strategic Management Journal, 23, 285-305.

McGunagle, D.M. (2007). The Chinese Auto Industry: Taming the Dragon. VDM Verlag Dr. Muller.

Mowery, D. C., Oxley, J. E. \& Silverman, B. S. (1996). Strategic Alliances and Interfirm Knowledge Transfer. Strategic Management Journal, 17, Special Issue, Winter, 77-92.

Newburry, W., \& Zeira, Y. (1997). Implications for Parent Companies. Journal of World Business, 32, 87-102.

Parkhe, A. (1993). "Messy" Research, Methodological Predispositions, and Theory Development in International Joint Ventures. Academy of Management Review, 18(2), 227-268.

Pavlovich, K. \& Akoorie, M. (2003). Strategic Alliances and Collaborative Partnership: A Case Book. Palmerston North: Dunmore Press.

Pearce, R.J. (1997). Toward Understanding Joint Venture Performance and Survival: A Bargaining and Influence Approach to Transaction Cost Theory. Academy of Management Review, 22(1), 203-225.

Penrose, E. T. (1959). The Theory of the Growth of the Firm. New York: Wiley.

Schuler, R.S. \& Tarique, I. (2006). Alliance Forms and Human Resource Issues, Implications, and Significance. In Shenkar, O. \& Reuer, J.J. (Eds.). Handbook of Strategic Alliances. Thousand Oaks: SAGE Publications. 
Spender, J. C. (1996). Making Knowledge the Basis of the Dynamic Theory of the Firm. Strategic Management Journal, $17,45-62$.

Steensma, K. \& Lyles, M. A. (2000). Explaining IJV Survival in a Transitional Economy through Social Exchange and Knowledge-based Perspectives. Strategic Management Journal, 21(8), 831-852.

Tallman, S. \& K. Fladmoe-Lindquist (2002). Internationalization, Globalization, and Capability-Based Strategy. California Management Review, 45(1), 116-135.

Tallman, S. (2005). Forming and Managing Shared Organization Ventures: Resources and Transaction Costs. In D. Faulkner \& M. De Rond (Eds.), Cooperative Strategy: Economic, Business, and Organizational Issues. Oxford University Press.

Williamson, O. E. (1975). Markets and Hierarchies. New York: Free Press.

Williamson, O. E. (1996). The Mechanisms of Governance. Oxford: Oxford University Press.

Yan, Y. (2000). International Joint Ventures in China: Ownership, Control and Performance. Macmillan Press Ltd.

Zajac, E.J. \& Olsen, C.P. (1993). From Transaction Cost to Transactional Value Analysis: Implications for the Study of Inter-organizational Strategies. Journal of Management Studies, 30(1), 131-145.

Table 1. Ways of transferring knowledge: advantages and disadvantages

\begin{tabular}{|c|c|c|}
\hline $\begin{array}{c}\text { Knowledge Development } \\
\text { Within company }\end{array}$ & $\begin{array}{c}\text { Alliances as Learning } \\
\text { Instrument }\end{array}$ & $\begin{array}{c}\text { Purchase of Relevant } \\
\text { Knowledge in the Market }\end{array}$ \\
\hline Advantages & $\begin{array}{c}\text { Emergence of New } \\
\text { Knowledge }\end{array}$ & Purchased based on Goods \\
\hline Control over Knowledge & Implicit Knowledge Transfer & No dependence on Facilities \\
\hline Lead over Competitors & $\begin{array}{c}\text { Building up Problem-Solving } \\
\text { Potential }\end{array}$ & \\
\hline Disadvantages & $\begin{array}{c}\text { Danger of Knowledge } \\
\text { Leakage }\end{array}$ & $\begin{array}{c}\text { Cost-intensive } \\
\text { Cost-intensive }\end{array}$ \\
\hline Time-consuming & $\begin{array}{c}\text { Knowledge Transfer Barriers } \\
\text { must be deleted }\end{array}$ & $\begin{array}{c}\text { Limited Availability of } \\
\text { Relevant Knowledge }\end{array}$ \\
\hline Few Incentives & & $\begin{array}{c}\text { Implicit Knowledge Transfer } \\
\text { is Difficult }\end{array}$ \\
\hline
\end{tabular}

Source: Adapted from Buchel et al. (1998).

\begin{tabular}{|c|c|c|c|c|c|}
\hline \multirow[t]{2}{*}{$\begin{array}{c}\text { Short- } \\
\text { term } \\
\text { Contracts }\end{array}$} & $\begin{array}{l}\text { Relational } \\
\text { Contracts } \\
\text { (e.g., Turn- } \\
\text { Key Projects } \\
\text { or Training }\end{array}$ & $\begin{array}{c}\text { Medium } \\
\text { Term } \\
\text { Contractual } \\
\text { Relationship }\end{array}$ & $\begin{array}{l}\text { Medium to } \\
\text { Long Term } \\
\text { Supply Chain } \\
\text { Relationship }\end{array}$ & $\begin{array}{c}\text { Equity Joint } \\
\text { Ventures }\end{array}$ & $\begin{array}{c}\text { Complete } \\
\text { Merger, } \\
\text { Acquisition, } \\
\text { Greenfield } \\
\text { Subsidiary }\end{array}$ \\
\hline & er / Shorter & $\begin{array}{l}\text { Expected I } \\
\text { Mutual C } \\
\end{array}$ & $\begin{array}{l}\text { ngevity } \\
\text { nmitment }\end{array}$ & & \\
\hline
\end{tabular}

Figure 1. A Spectrum of Inter-Organizational Cooperative Arrangements 


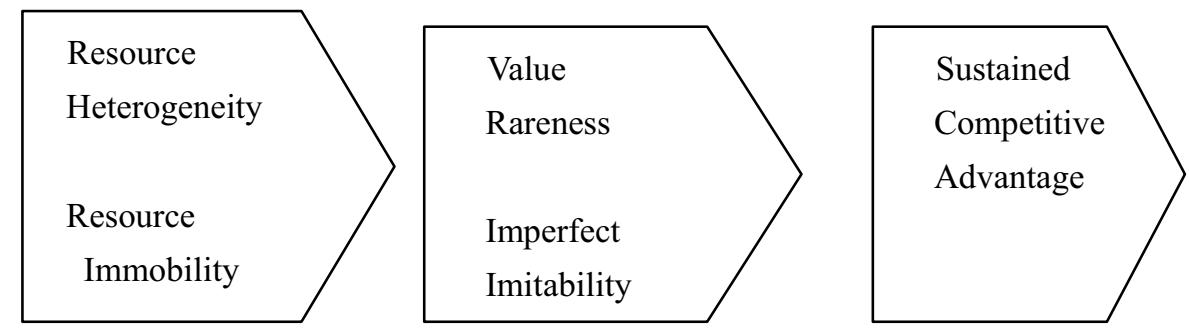

Figure 2. Resource-based Theory (RBT) Model of SCA

Source: Barney \& Clark (2007, p. 69). 